\title{
Organizational and Demographic Level Diversity Practices and Employees Performance
}

\author{
Mohammad Qasim (D) ${ }^{1}{ }^{1}$, Abdul Qahar (D) ${ }^{2}$, Raza Ullah (D) ${ }^{3}$ \\ Faculty of Economics, Kardan University, Kabul Afghanistan ${ }^{1}$ \\ Iqra National University, Peshawar, Pakistan ${ }^{2}$ \\ Islamia College University, Peshawar, Pakistan ${ }^{3}$
}

\section{ABSTRACT}

Purpose - The study's primary objective was to investigate the relationship between organizational level diversity practices, demographic level diversity practices, and employees ' performance at selected higher educational institutions in Kabul, Afghanistan.

Findings - The findings support a positive relationship between variables; furthermore, the study revealed high contributive implications in both academic and non - academic arena. Moreover, the research suggests, diversity management practices must be considered critical as they can contribute to employees performance.

Sampling - For the current study, four major universities were selected. A total of 100 questionnaires were distributed, respondents were asked to mention their demographic characteristics, and answered the questions from (1) strongly disagree to (5) agree.

Analysis - The current study used SPSS 24.0 version for data analysis collected from the respondents; some necessary regression tests were implemented for the study.

\section{ARTICLE INFO}

Received: December 27, 2020

Revised: January 10, 2021

Accepted: January 11, 2021

Published: January 11, 2021

\section{Keywords:}

Diversity Management

OLDP

DLDP

Employees Performance

(cc) BY (C) 2021 The Author(s)

$\triangle$ Corresponding author: m.qasim@kardan.edu.af

\section{Introduction}

In both academic and non-academic organizations, the interest in diversity management practices has increased and is considered a fundamental strategy of organizational competitiveness. Diversity management practices are the most commonly utilized and considered proactive towards organizational and employee performance (Roberson et al., 2003). Management of diversity, without a doubt, is willing to adopt quality decisions between discrepancies and similarities (Roberson et al., 2003). Diversity management practices contribute to improved organizational structure and individual effective and efficient performance (Binnall, 2019; Richter et al., 2012). Much earlier literature supports diversity management towards understanding, some 
other (Binnall, 2019; Richter et al., 2012; Aydan, 2016; Cox et al., 1991; Bassett-Jones, 2005) believes diversity management supports the creativity of individuals (Daver \& Demirel, 2012)

Considering increased interest in diversity management, it has been shown that successful diversity management is a critical indicator toward positive employee outcomes; for instance, greater job satisfaction leads to higher results (Rainey, 2009). In particular, Asian nations have less devotion given to diversity management. It is all because of a misunderstanding or miss-conception (Cho \& Barak, 2008). Studies focused on two views positive and negative consequences of diversity in diversified work-group, while few focused on diversity management and the influence on employee's behavior and work attitude, for instance (Bassett-Jones, 2005)

But the question is how it impacts employee's performance attitude, which still needs to be uncovered. Some researchers (Prieto \& others, 2011) explored diversity management contribution toward employee's positive work attitude. Therefore, the study's primary focus on hand is (1) to explore diversity management practices' relationship towards an individual's performance in selected higher educational institutions in Afghanistan. (2) to highlight the advantages of the chosen approaches towards understanding. (3) the impact of organizational level diversity management practices on individual performance. Particular in male-dominated societies. Finally, (4) Demographic diversity practices and employee's performance. The study's significant contribution lies in exploring organizational and demographic diversity management practices towards implementing individuals working in the higher institution in Afghanistan. Furthermore, the study examines the necessity of utilizing corporate and demographic diversity management practices in man-dominated societies.

\section{Literature Review}

\section{Organizational Level Diversity Practices}

Managing employees in higher educational institutions of Afghanistan is one of the most fundamental issues. Academicians from different countries, Pakistan, India, Malaysia, and local Afghan nationals, serve in other institutions. Researchers (Hen et al., 2014)believe managing diversity plays a crucial role in organizational constancy, particularly financial stability. (Hen et al., 2014) explored different organizational-related diversity (e.g., Recruitment and selection, reward and promotion, leadership). (Madera, 2013) studied seven classes of diversity management. (Cho \& Barak, 2008) associated diversity inventiveness, which took by the hospitality and non-hospitality organizations. While (Heylen et al., 2006) proposed diversity management examples that are effective for hospitality industries.

Diversity (Blau, 1977) defined the significant number of the population distributed in different statues. (Wirth, 1977) define the term diversity management as the exploitation of HR practices (growth or preservation of human capital dissimilarity, ensuring that each human capital dissimilarity doesn't delay the organizational goals and achievements. On the other hand (Pitts, 2005) well-defined with consideration of various definitions, he believes the main focus of managing diversity means ensuring that organizational functions and overall processes serve equally regardless of age, gender, race, nationality, and physical condition. Given the social exchange theory, employees' result-oriented behavior can result from fair treatment and management support (Heath \& Leichty, 2014). The study on hand views diversity management as all organizational practices designed to ensure fairness in the organization's policies and procedure that leads employees to serve effectively (Buttner et al., 2010).

H1: Organizational level diversity practices have a significant correlation with employee's performance working in higher institutions.

\section{Demographic Level Diversity Practices}


Diversity is related to demographics defined as differences among individuals (employees) in terms of age, gender, race, and ethnicity (Baugh, S. G., \& Graen, G. B. 1997; Shore, L. M., Cleveland, J. N., \& Goldberg, C. B., 2003). Demographic diversity is a phenomenon that affects performance at a different level (Heylen et al., 2006). A working environment that recognizes the contribution from divers demographic dissimilarities (gender, age, ethnicity) together (Lenstra et al., 2012; Gottman et al., 1998) needs a collective understanding of practitioners to exploit the possible outcomes. Social identity theory suggests that individuals distinguish their uniqueness and identity within society, categorizing themselves into different specific groups, for instance, gender, age, and ethnicity knowledge (Turner et al., 1979). This theory (Social identity) helps individuals share the same morals, which primes indulge their group members (Voci \& Hewstone, 2003).

Ethnicity is considered a social category of population who have perceived common cultural and language traditions apart from other societies (Voci \& Hewstone, 2003). Because of the shared and common culture and traditions, a group of people identified as specific ethnic (Lenstra et al., 2012). Gender is understood as male and female (Zingone et al., 2005). For instance, researchers (Dwyer et al., 2003; and (Shaw et al., 2019) believe that differences in men and women cause job performance. Religion is the external characteristics (Rodgers \& Hunter, 2003). The set of beliefs are known as religion (J. Rodgers, 2003). Religion comes under ethnicity, and it is a set of ideas (Corp, 2008). Considering the demographic diversity (Ethnicity, gender, and Religion) aspects, the current study test the following (H2) research hypothesis.

H2: Demographic level diversity practices have a significant correlation with employee's performance working in higher institutions

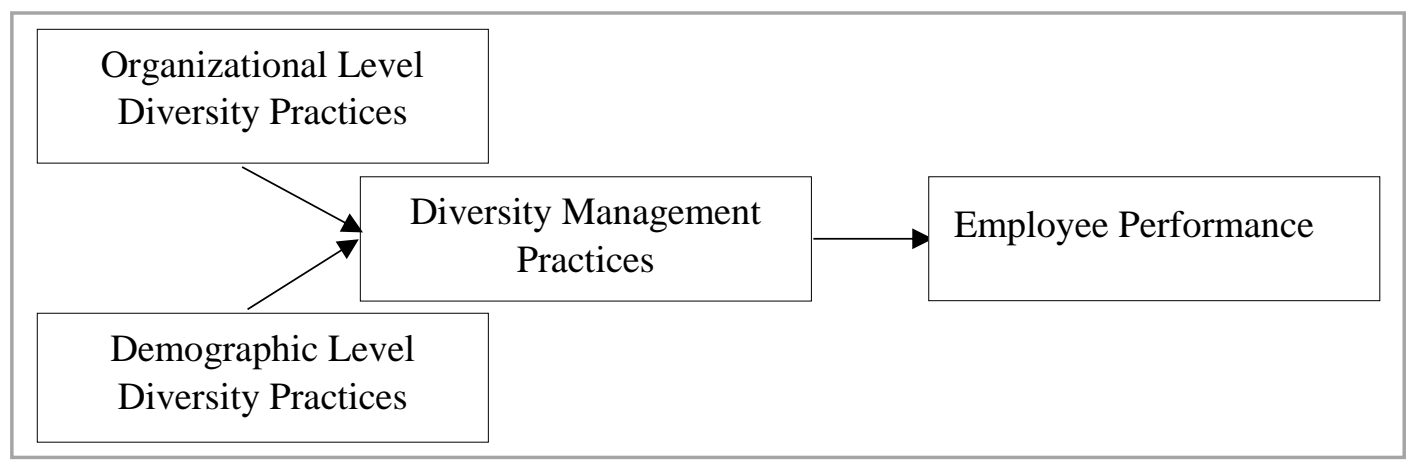

Figure 1 - Theoretical Model

\section{Methodology}

\section{Research Design}

The study is a quantitative, convenient sampling technique used for the data collection from the selected higher educational institutions (e.g., Kardan University, Bakhtar University, Rana University, and Donya University) diversified employees from different countries. Questionnaires were distributed among 100 respondents. Two demographic related (Age, gender, education, experience, designation, organization) questions were asked, while the second portion question about variables was queried from the respondent.

\section{Population and Sample Size}

For the current study, we targeted different higher educational institutions serving in Kabul, the capital of Afghanistan; among the top 15 universities, four universities were selected for data collection; the established university names are mentioned in the last portion of table 1; they were Kardan University, Bakhtar University, Rana University, and Donya University. We didn't choose a sample size for this study. Based on security 
conditions and many threats, we tried to distribute questionnaires randomly among the participant who wanted to participate in the study; the number of participants is also mentioned in table 1 under the organization heading.

\section{Measurements and Reliability Statistics}

Organizational Level Diversity Practices 10 items scale were given (Choi \& Rainey, 2014), Demographic Level Diversity Practices 10 items from (Shaw et al., 2019; Deogracias et al., 2007; and Allen \& Meyer, 1990). Employees Performance Table 6; explains the value for each questionnaire scale. OLD is having ten items = .796 , next DLD having ten items $=.618$, and EP having eight items $=.856$, the reliability for each scale for this study was acceptable.

Table 1 - Reliability Statistics

\begin{tabular}{lll}
\hline Variables & Values & N of Items \\
\hline Organizational Level Diversity & .796 & 10 \\
Demographic Level Diversity & .618 & 10 \\
Employees Performance & .856 & 8 \\
\hline
\end{tabular}

\section{Data Analysis}

Table 2 - Demographic details

\begin{tabular}{lllll}
\hline Age & Frequency & Percent & Valid \% & Cumulative \% \\
\hline $25-30$ & 32 & 32.0 & 32.0 & 32.0 \\
$31-40$ & 42 & 42.0 & 42.0 & 74.0 \\
$41-$ Above & 26 & 26.0 & 26.0 & 100.0 \\
Gender & & & & \\
Male & 86 & 83.0 & 83.0 & 86.0 \\
Female & 17 & 17.0 & 17.0 & 100.0 \\
Educational Level & & & & \\
Master Degree & 68 & 68.0 & 68.0 & 68.0 \\
Ph.D. In Progress & 24 & 24.0 & 24.0 & 92.0 \\
Ph.D. Holder & 8 & 8.0 & 8.0 & 100.0 \\
Designation & 20 & & & \\
Lecturer & 48 & 20.0 & 20.0 & 20.0 \\
Assistant Professor & 22 & 48.0 & 48.0 & 68.0 \\
Associate Professor & 10 & 22.0 & 22.0 & 90.0 \\
Professor & & 10.0 & 10.0 & 100.0 \\
Organization & 36 & 36.0 & 36.0 & 36.0 \\
Kardan University & 15 & 15.0 & 15.0 & 51.0 \\
Bakhtar University & 21 & 21.0 & 21.0 & 72.0 \\
Rana University & 28 & 28.0 & 28.0 & 100.0 \\
Donya University & 100 & 100.0 & 100.0 & \\
Total & & &
\end{tabular}

Table 2 represents all demographic characteristics (age, gender, educational level, designation, and organization). At the first portion, the respondent's age showed that $42=42.0 \%$ marked themselves having age between $31-40,32=32.0 \%$ were having age between $25-30$, while 26 respondents had $41-$ above which is equal to $26.0 \%$. In table 1, the second portion represents the Gender of the participant; it showed $83.0 \%$ are male while only $17.0 \%$ is the female respondent for the study; the study statistically represented more male respondent for the questionnaire. Next, we statistically explored the educational level of the participant. As a result, we had $68.0 \%$ of the respondents from Master's degree holders, $24.0 \%$ of a participant having a Ph.D. degree in progress, while only $8.0 \%$ were complete Ph.D. holders. 
Furthermore, we also asked the participant to mention their designation most of the participant working as an assistant professor; the valid percent was $48.0 \%$, while the second-highest result $22.0 \%$ marked as associate professors, $20.0 \%$ lecturers, and only $10.0 \%$ of the respondent were complete professors for the current study. Its shows that the participant was matured enough to participate and provide their feedback in the survey. Finally, the last portion statistically represents the organization where the participant was asked to mention the organization they are working in. The result was as following, for Kardan university $=36.0 \%$, Bakhtar University $=15.0 \%$, Rana University $=21.0 \%$ and Donya University $=28.0 \%$.

\section{Regression Analysis}

Table 3 - Model Summary

\begin{tabular}{llll}
\hline $\mathbf{R}$ & R Square & Adjusted R Square & Std. The error of the Estimate \\
\hline .491 & .582 & .682 & .37357 \\
a. Predictors: (Constant), ORDP, DLDP & &
\end{tabular}

Table 3 model summary shows $\mathrm{R}$ Square, which is equal to .582. This means $58.2 \%$ change independent variable (Employees performance) due to independent variables (organizational level diversity practices \& demographic level diversity practices).

Table 4 - ANOVA

\begin{tabular}{llllll}
\hline & Sum of Squares & df & Mean Square & F & Sig. \\
\hline Regression & 756.173 & 2 & 378.087 & 2709.241 & .000 \\
Residual & 13.537 & 97 & .140 & & \\
Total & 769.710 & 99 & & & \\
a. Dependent Variable: Employees Performance & & & \\
b. Predictors: (Constant), OLDP, DLDP & & & & \\
\hline
\end{tabular}

According to Anova (table 4), the significant level is .000, which shows that the model fits the study.

Table 5 - Coefficient

\begin{tabular}{llllll}
\hline & \multicolumn{2}{l}{ Unstandardized Coefficients } & Standardized Coefficients & t & Sig. \\
\cline { 2 - 6 } & $\mathrm{B}$ & Std. Error & Beta & 8.276 & .000 \\
(Constant) & 3.646 & .441 & & 10.089 & .000 \\
OLDP & .225 & .022 & .346 & 19.368 & .000 \\
DLDP & .495 & .026 & .564 & & \\
a. Dependent V Variable: Employees Performance & & & \\
\hline
\end{tabular}

Coefficient (table 5) regression results show the explanatory variable; the table explains beta coefficient for organizational level diversity practices is .346, the standard error value is shown .022, which further explains into at-statistics 10.089, which discusses at 5\% level statistically significant. Furthermore, the beta coefficient for demographic level diversity practices is .564, with an explored standard error.026, This result translates into at-statistics 19.368 , which makes the relationship statistically significant at the $5 \%$ level.

Table 6 - Correlation between OLD, DLD, and EP

\begin{tabular}{|c|c|c|c|}
\hline Organizational Level Diversity & Pearson Correlation & 1 & \\
\hline Practices & Sig. (2-tailed) & & \\
\hline$(R \& S, T \& D, P A)$ & $\mathrm{N}$ & 100 & \\
\hline & Pearson Correlation & $.820^{* *}$ & 1 \\
\hline Demographic Level Diversity Practices & Sig. (2-tailed) & .000 & \\
\hline
\end{tabular}




\begin{tabular}{|c|c|c|c|c|}
\hline \multirow[t]{2}{*}{ (Religion, Ethnicity, Gender) } & $\mathrm{N}$ & 100 & 100 & \\
\hline & Pearson Correlation & $.856^{* *}$ & $.882^{* *}$ & 1 \\
\hline Employees Performance & Sig. (2-tailed) & .000 & .000 & \\
\hline (Higher Educational Institution) & $\mathrm{N}$ & 100 & 100 & 100 \\
\hline
\end{tabular}

In (Table 6), the correlation between variables is statistically explained. The correlation between organizational level diversity practices and employee performance is positive, with .820 at a $5 \%$ significance level. There is also a positive relationship between demographic-level diversity practices and employee performance at a given value .856 , at a $5 \%$ significance level.

\section{Results and Discussion}

The study's primary purpose was to investigate the relationship between (IV) organizational and demographic level diversity practices and (DV) employee performance at a selected higher educational institution in Kabul, Afghanistan. The correlation table explained a positive relationship between the variables organizational level diversity practices and employee's performance shown positive with .820 at $5 \%$ significance level; there is also a positive relationship between demographic level diversity practices and employees performance at given value .856, at 5\% significance level. $\mathrm{R}$ Square value is .582 means $58.2 \%$ change because of the independent variable. The coefficient regression results show the explanatory variable; the table explains the beta coefficient for organizational level diversity practices is .346. The standard error value is shown .022, which further explains into a t-statistics 10.089 discusses at 5\% level statistically significant.

The study investigates the effect of the organizational level diversity and the demographic level effect on the employees 'performance in Kabul's selected universities. As the previous literature is studied, they previous literature has contributed indicated the significance relationship between the organizational level diversity and the employees Researcher (Gentekaki, E et al., 2017) proposed that the management of the organizational level diversity adds value the organizational constancy, precisely the financial stability.

Also, the literature has contributed to the significant relationship between demographic level diversity and the performance of employees' Demographic diversity. It is the used terminology explaining the difference in Gender, Religion, and Ethnicity whose management has a considerable influence on the individual (Van Knippenberg et al., 2004). Hence the impact of the organizational level diversity and the demographic level diversity are tested statically significant. Our alternate hypothesis is accepted and supported by both the literature and the analysis. Furthermore, all hypothesis is accepted.

\section{Conclusion}

The finding of the study has high contributive implication in business and in particular to the academic arena. The study revealed a positive relationship between selected variables, while the study suggests the better implementation of the organization's diversity practices. Furthermore, the study was quantitative; a convenient sampling technique was used. Also, 100 questionnaires were distributed among selected employees working in different universities in Kabul, Afghanistan. For the current study, the various tests have been implemented, e.g., we explored with frequency analysis for demographic. For variables, we used to implement the model summary, coefficient, correlation, and ANOVA test. IBM. SPSS 24.0 was used to complete quantitative data analysis.

\section{Limitation and Future Direction}

The study revealed a positive between variables, practices related to organizational level diversity, and demographic level diversity considered adequate toward employee's performance. As with every research study, we also have some limitations and future research direction. 
First: For the current study, social exchange and social identity theories are associated with demographic diversity practice only. At the same time, future studies may focus on some other theories related to employee performance. Second: Due to uncertain security conditions in the country, we only collected data from few number 100 respondents, further studies may increase the number of the respondent to explain the relationship between variables well. Third: the current research explored the relationship between independent and dependent variables; other studies may focus on some mediating or moderating variables. Fourth: the survey of hand targeted selected higher institutions, while future research can target other sectors. For example, the bank sector, manufacturer firms, and other firms such as pharmaceutical companies.

Funding: This research received no external funding.

Acknowledgments: We acknowledge there was no external funding support; all authors contributed accordingly in every part of the paper.

Conflicts of Interest: The authors declare no conflict of interest.

\section{References}

Allen, N. J., \& Meyer, J. P. (1990). The measurement and antecedents of affective, continuance, and normative commitment to the organization. Journal of Occupational Psychology, 63(1), 1-18. https://doi.org/10.1111/j.2044-8325.1990.tb00506.x

Austin, J. R. (1997). a Cognitive Framework for Understanding Demographic Influences in Groups. The International Journal of Organizational Analysis (Vol. 5, Issue 4, pp. 342-359). https://doi.org/10.1108/eb028873

Aydan, O. (2016). The effects of diversity management on job satisfaction and individual performance of teachers. Educational Research and Reviews, 11(3), 105-112. https://doi.org/10.5897/err2015.2573

Ayeri, O. S., Christian, V. R., Josef, E., \& Michael, H. (2012). Local perceptions and responses to climate change and variability: The case of Laikipia District, Kenya. Sustainability, 4(12), 3302-3325. https://doi.org/10.3390/su4123302

Bassett-Jones, N. (2005). The paradox of diversity management, creativity, and innovation. Creativity and Innovation Management, 14(2), 169-175. https://doi.org/10.1111/j.1467-8691.00337.x

Binnall, J. M. (2019). Jury diversity in the age of mass incarceration: an exploratory mock jury experiment examining felon-jurors' potential impacts on deliberations. Psychology, Crime and Law, 25(4), 345363. https://doi.org/10.1080/1068316X.2018.1528359

Blau, P. M. (1977). A Macrocosial Theory of Social Structure. In American Journal of Sociology (Vol. 83, Issue 1, pp. 26-54).

Buttner, E. H., Lowe, K. B., \& Billings-Harris, L. (2010). Diversity climate impact on employee of color outcomes: Does justice matter? Career Development International, 15(3), 239-258. https://doi.org/10.1108/13620431011053721

Cho, S., \& Barak, M. E. M. (2008). Understanding of diversity and inclusion in a perceived homogeneous culture: A study of organizational commitment and job performance among Korean employees. Administration in Social Work, 32(4), 100-126. https://doi.org/10.1080/03643100802293865

Choi, S., \& Rainey, H. G. (2014). Organizational Fairness and Diversity Management in Public Organizations: Does Fairness Matter in Managing Diversity? Review of Public Personnel Administration, 34(4), 307331. https://doi.org/10.1177/0734371X13486489

Corp, T. S. (2008). No Title血清及尿液特定蛋白检测在糖尿病肾病早期沴断中的意义. 2-5.

Cox, T. H., Lobel, S. A., \& McLeod, P. L. (1991). Effects of Ethnic Group Cultural Differences on Cooperative and Competitive Behavior On a Group Task. Academy of Management Journal, 34(4), 827-847. https://doi.org/10.5465/256391

Daver, F., \& Demirel, B. (2012). A simulation study of the effect of preform cooling time in injection stretch 
blow molding. Journal of Materials Processing Technology, 212(11), 2400-2405.

https://doi.org/10.1016/j.jmatprotec.2012.06.004

Deogracias, J. J., Johnson, L. L., Meyer-Bahlburg, H. F. L., Kessler, S. J., Schober, J. M., \& Zucker, K. J.

(2007). The gender identity/gender dysphoria questionnaire for adolescents and adults. Journal of Sex Research, 44(4), 370-379. https://doi.org/10.1080/00224490701586730

Dwyer, S., Richard, O. C., \& Chadwick, K. (2003). Gender diversity in management and firm performance:

The influence of growth orientation and organizational culture. Journal of Business Research, 56(12),

1009-1019. https://doi.org/10.1016/S0148-2963(01)00329-0

Effects_of_Team_Gender_and_Racial_Composition_on_P.pdf. (n.d.).

Gottman, J. M., Coan, J., Carrere, S., Swanson, C., Gottman, J. M., Coan, J., Carrere, S., \& Swanson, C. (1998). Predicting Marital Happiness and Stability from Newlywed Interactions Published by:

National Council on Family Relations Predicting Marital Happiness and Stability from Newlywed Interactions. Journal of Marriage and Family, 60(1), 5-22. https://doi.org/10.1002/job

Heath, R., \& Leichty, G. (2014). Social Exchange Theory. Encyclopedia of Public Relations. https://doi.org/10.4135/9781452276236.n454

Heylen, K., Vanparys, B., Wittebolle, L., Verstraete, W., Boon, N., \& De Vos, P. (2006). Cultivation of denitrifying bacteria: Optimization of isolation conditions and diversity study. Applied and Environmental Microbiology, 72(4), 2637-2643. https://doi.org/10.1128/AEM.72.4.2637-2643.2006

Jin, H., \& Martin, C. (1999). Multifunctionality and diversity within the plant MYB-gene family. Plant Molecular Biology, 41(5), 577-585. https://doi.org/10.1023/A:1006319732410

Lee, S. (2010). 기사 (Article) 와 안내문 (Information) [. The Electronic Library, 34(1), 1-5.

Lenstra, J. A., Groeneveld, L. F., Eding, H., Kantanen, J., Williams, J. L., Taberlet, P., Nicolazzi, E. L., Sölkner, J., Simianer, H., Ciani, E., Garcia, J. F., Bruford, M. W., Ajmone-Marsan, P., \& Weigend, S. (2012). Molecular tools and analytical approaches for the characterization of farm animal genetic diversity. Animal Genetics, 43(5), 483-502. https://doi.org/10.1111/j.1365-2052.2011.02309.x

Madera, J. M. (2013). Best Practices in Diversity Management in Customer Service Organizations: An Investigation of Top Companies Cited by Diversity Inc. Cornell Hospitality Quarterly, 54(2), 124 135. https://doi.org/10.1177/1938965513475526

Milliken and Martins, L. L. (1996). Searching for Common Threads : Understanding the Multiple Effects of Diversity in Organizational Groups Author ( s ): Frances J. Milliken and Luis L. Martins Source : The Academy of Management Review, Vol . 21, No . 2 (Apr ., 1996 ), pp. 402-433 Pub. Academy of Management Review, 21(2), 402-433.

Pitts, D. (2005). Pitts 2009 Diversity Management Job Satisfaction and Performance.

Prieto, L., \& others. (2011). Linking Workplace Diversity To Organizational Performance: A Conceptual Framework. Journal of Diversity Management (JDM), 4(4), 13-22. http://journals.cluteonline.com/index.php/JDM/article/view/4966

Proceedings_acp_part.pdf. (n.d.).

Rainey, H. G. (n.d.). Managing Diversity in U.S. Federal Agencies: Effects of Diversity and Diversity Management on Employee Perceptions of Organizational Performance.

Richter, A. W., Hirst, G., van Knippenberg, D., \& Baer, M. (2012). Creative self-efficacy and individual creativity in team contexts: Cross-level interactions with team informational resources. Journal of Applied Psychology, 97(6), 1282-1290. https://doi.org/10.1037/a0029359

Roberson, L., Kulik, C. T., \& Pepper, M. B. (2003). Using needs assessment to resolve controversies in diversity training design. Group and Organization Management, 28(1), 148-174. https://doi.org/10.1177/1059601102250028

Rodgers, J. O., \& Hunter, M. (2003). Effective Diversity Management. Handbook of Business Strategy, 4(1), 222-227. https://doi.org/10.1108/eb060272

Shaw, F. A., Malokin, A., Mokhtarian, P. L., \& Circella, G. (2019). It's not all fun and games: An investigation 
of the reported benefits and disadvantages of conducting activities while commuting. Travel Behaviour and Society, 17, 8-25. https://doi.org/10.1016/j.tbs.2019.05.008

Shen, C., Liang, W., Shi, Y., Lin, X., Zhang, H., Wu, X., Xie, G., Chain, P., Grogan, P., \& Chu, H. (2014). Contrasting elevational diversity patterns between eukaryotic soil microbes and plants. Ecology, 95(11), 3190-3202. https://doi.org/10.1890/14-0310.1

Turner, J. C., Brown, R. J., \& Tajfel, H. (1979). Social comparison and group interest in ingroup favouritism. European Journal of Social Psychology, 9(2), 187-204. https://doi.org/10.1002/ejsp.2420090207

Van Knippenberg, D., De Dreu, C. K. W., \& Homan, A. C. (2004). Work group diversity and group performance: An integrative model and research agenda. Journal of Applied Psychology, 89(6), 10081022. https://doi.org/10.1037/0021-9010.89.6.1008

Voci, A., \& Hewstone, M. (2003). Intergroup Contact and Prejudice Toward Immigrants in Italy: The Mediational Role of Anxiety and the Moderational Role of Group Salience. Group Processes \& Intergroup Relations, 6(1), 37-54. https://doi.org/10.1177/1368430203006001011

Wirth, N. (1977). What Can We Do about the Unnecessary Diversity of Notation for Syntactic Definitions? Communications of the ACM, 20(11), 822-823. https://doi.org/10.1145/359863.359883

Zingone, A., Percopo, I., Sims, P. A., \& Sarno, D. (2005). Diversity in the genus Skeletonema

(Bacillariophyceae). I. A reexamination of the type material of S. costatum with the description of $S$. grevillei sp. nov. Journal of Phycology, 41(1), 140-150. https://doi.org/10.1111/j.1529-

8817.2005.04066.x 